\title{
The Unsung One: The Performer's Voice in Twentieth-century Musical Monodrama
}

\section{Francesca Placanica}

To cite this article: Francesca Placanica (2018) The Unsung One: The Performer's Voice in Twentieth-century Musical Monodrama, Journal of Musicological Research, 37:2, 119-140, DOI: 10.1080/01411896.2017.1381522

To link to this article: https://doi.org/10.1080/01411896.2017.1381522

\section{Published online: 19 Apr 2018.}

\section{Submit your article to this journal}

\section{Џll Article views: 230}

Q View related articles $\longleftarrow$

View Crossmark data $₫$ 


\title{
The Unsung One: The Performer's Voice in Twentieth-century Musical Monodrama
}

\author{
Francesca Placanica (1) \\ Maynooth University
}

\begin{abstract}
In an examination of the evident yet overlooked subject of the singing body in opera studies, focusing on the soloist's voice and role in twentieth-century musical stage works for a single performer offers a number of engaging insights. By observing contemporary staging and practices in light of current performance theories and studies of voice and opera, it is possible to construct an alternative reading of the performer's embodied voice in musical monodrama, until now not fully addressed in the opera studies discourse. I argue that the performer's agency should be redefined as a compelling extra-text to be asserted both theoretically and practically in the discourse and production surrounding twentieth-century monodrama and music theater stage works for one performer.
\end{abstract}

This article offers insights into the evident yet overlooked subject of the singing body in opera and music-theater studies by focusing on the performative voice of the soloist in twentieth-century musical stage works for one vocalist. My research supports the hypothesis that the immanent performativity of this body of work is profoundly inherent to the dramatic form, and explores the functional connections between historical and current practices of embodiment in staging. ${ }^{1}$ From a performance-studies standpoint, John L. Austin's description of performative utterances-"by saying or in saying something we are doing something"-perfectly adheres to the poietic quality of the solo's vocal delivery in musical monodrama. ${ }^{2}$ In my opinion, musical monodrama represents a formidable arena for the performative power of the singing voice. In this dramatic form, the solo's embodied voice utters sonically through its corporeal agency, affecting reality and communication mechanisms, generating and shaping the dramatic physical space, and ultimately crowning the performer's body as a dramatic locus in its own right-a

\footnotetext{
${ }^{1}$ I refer here to research work undertaken in the framework of my Irish Research Council-funded project, "EnGendering Monodrama: Artistic Research and Experimental Production" (2015-17), hosted at Maynooth University, Ireland.

2John L. Austin, How to Do Things With Words (London: Oxford University at Clarendon Press, 1962), 12.

(c) 2018 Taylor \& Francis
} 
"performative body space." Monodrama therefore incarnates quintessentially the performer not only in her/his capacity of having a body but of being a body. ${ }^{4}$ The fact that many twentieth-century monodramas stage, de facto, structured inner monologues (for example. Erwartung, Eight Songs for a Mad King, Recital I, The Medium, and Melodrama, to name but a few) highlights the agential primacy of the performer's voice as an archetypal bridge between the voice's self-assertion through unconscious monologue, the body of the protagonists as stage figures, and their identities as performative personae. Musical monodrama's embodied nature, however, also seems to produce a virtual "impasse," which makes this stage form hard to define unilaterally and to consume as a standalone piece. This is perhaps due to the fact that, despite the evident character of agency entrusted to the soloist, its production has been mostly absorbed in the standard operatic regime. As things now stand, in the chain of determinations contributing to a monodramatic production and in line with current operatic-production politics applied to larger-scale operas, the performer remains at the bottom of the production process, the executioner of performative prescriptions superimposed by a number of authorities, often impermeable to one another, if not conflicting. The result we witness as spectators is the evident negation of the agency of the performer's embodiment through the complaisant display of the performer's branded identity: hence the "operatic scandal of the singing body" results emphasized in the "monodramatic impasse" produced by the one woman's presence on stage. ${ }^{5}$ My ultimate argument is that the agency of the solo performer in these works should be at least asserted as a defining premise in the discourse surrounding this repertoire. Even if inscribed within a larger appraisal of stage works for one interpreter spanning the twentieth and twenty-first centuries, my observations arise in particular from practice and research based so far on a few modernist compositions for female solo: Francis Poulenc's La Voix humaine (1959), Luciano Berio's Recital I (for Cathy) (1972), and Morton Feldman's Neither (1977), although some insights into Peter Maxwell Davies' Eight Songs for a Mad King (1969) for male voice will also support my discussion.

\section{Musical monodrama: Attempting a definition}

To quote New York Times critic Anthony Tommasini's review of the $2011 \mathrm{New}$ York City Opera production Monodramas, featuring three one-act/one-female-

\footnotetext{
${ }^{3}$ The body has in fact a performative role as a producer of cultural and social spaces, molds political and social choreographies, transgresses gender, or leads to modifications through performative visual and textual, medial and technological body spaces applied to body alterations. Markus Hallensleben, ed., Performative Body Spaces: Corporeal Topographies in Literature, Theatre, Dance, and the Visual Arts (Amsterdam, The Netherlands: Rodopi, 2010), 10.

${ }^{4}$ Helmuth Plessner, Laughing and Crying: A Study of the Limits of Human Behavior, trans. James Spencer Churchill and Marjorie Grene (Evanston, IL: Northwestern University Press, 1970), 34-5. Also quoted in Hallensleben, ed., Performative Body Spaces, 15.

${ }^{5}$ Here my formula of "monodramatic impasse" recalls theories first enunciated in Michelle Duncan, "The Operatic Scandal of the Singing Body: Voice, Performance, Performativity," Cambridge Opera Journal 16, no. 3 (2004): 285.
} 
soloist works, when approaching monodramas, "it is best to switch off the part of your brain that needs to know what an opera is about." ${ }^{\text {"I }}$ fact, looking specifically at each twentieth-century case, and the various guises in which modernist composers have inflected and defined the musical monologue, terminology clearly seems to vary from work to work, with each given a unique specification (see Table 1). ${ }^{7}$ Except for cases in which the definition of "monodrama" is deliberately used by the composer in the title page of the composition (perhaps as a reference to its literary legacy), these works have been labeled in different ways: monologue lyrique for soprano and orchestra (La dame de Montecarlo), tragédie lyrique for soprano solo (La Voix humaine), opera (Neither), or, as in the case of music-theatre pieces, not labelled at all. Arguably, defining the field where such exploration should take place becomes a difficult task: Some compositions were intended for the stage (Erwartung, La Voix humaine), others were implicitly dramatized (Recital I, La Dame de Montecarlo), and a work such as Neither-even if clearly labeled as opera-does not contain any staging or performance indications. Despite the manifest differences characterizing the style and scope of musical monodramas, it is nonetheless legitimate to note that these creations express a set of recognizable dramatic loci, whose modernist roots could perhaps be traced back to the archetype of Arnold Schoenberg's Erwartung (1909/1924) and the psychoanalytic ferment that spanned literature and performing arts at the beginning of the twentieth century. Due to its kinship with contemporary literary and philosophical inspirations, its musical interface has traditionally been connected to the legacy of eighteenth-century German melodrama, which featured only one character and in which speech alternated with sung passages. ${ }^{8}$ This conventional notion has been recently revisited, and the musical topos of a monologue set to music identifies with the notion of "monologue" or "recitation with music." In particular, the centrality of the stream of consciousness entrusted to the protagonist of these twentieth-century libretti eschews rigid formal and stylistic structures to the point that perhaps we might define musical monodrama as a compositional topos rather than a genre.

This was in line with the emphasis placed on realistic drama and with the disruption of conventional operatic formulae and languages at the turn of the

\footnotetext{
${ }^{6}$ Anthony Tommasini, "Who Killed this Woman's Lover? And Other Elusive Operatic Issues," New York Times, March 27, 2011, http://www.nytimes.com/2011/03/28/arts/music/monodramas-new-york-city-opera-one-acts-review. html?_r=1\&ref=todayspaper (accessed November 7, 2015). The event included Arnold Schoenberg's Erwartung, Morton Feldman's Neither, and John Zorn's La machine de l'être.

${ }^{7}$ Far from being an exhaustive census, Table 1 is a work in progress of staged musical monologues spanning the twentieth and twenty-first centuries.

${ }^{8}$ For extensive work on the genesis and development of solo-performance art genres and their relationship to the female body, see Carrie J. Preston, Modernism's Mythic Pose: Gender, Genre, Solo Performance (New York: Oxford University Press, 2011). See also Jessica Payette, Seismographic Screams: Erwartung's Reverberations through Twentieth-century Culture (Ph.D. Diss., Stanford University, 2008); more recently, Brian Inglis, "The Liminal Zone of Opera: (Unaccompanied) Operatic Monodrama and The Song of Margery Kempe," in Music on Stage, edited by Luis Campos and Fiona Jane Schopf, vol. 2 (Newcastle Upon Tyne: Cambridge Scholars, 2016), 171-90.

${ }^{9}$ Anne Dhu McLucas, "Monodrama," Oxford Music Online, Grove Music Online, http://www.oxfordmusiconline.com/ subscriber/article/grove/music/18976?q=monodrama\&search=quick\&pos=1\&_start=1\#firsthit (accessed May 2017).
} 
Table 1. List of monodramas in the twentieth and twenty-first centuries.

\begin{tabular}{|c|c|c|c|c|c|}
\hline Composer & Librettist & Title of work & Definition & Premiere & First Interpreter \\
\hline $\begin{array}{l}\text { Arnold } \\
\text { Schoenberg }\end{array}$ & Marie Pappenheim & Erwartung & Monodrama & 1924 & $\begin{array}{l}\text { Marie Gutheil- } \\
\text { Schoder }\end{array}$ \\
\hline $\begin{array}{l}\text { Hugo David } \\
\text { Weisgall }\end{array}$ & $\begin{array}{l}\text { Richard Henry Hart, } \\
\text { based on August } \\
\text { Strindberg }\end{array}$ & The Stronger & $\begin{array}{l}\text { Opera in one } \\
\text { act }\end{array}$ & 1952 & Eva Bober \\
\hline Roger Sessions & $\begin{array}{l}\text { Theocritus, translated } \\
\text { by R. C. Trevelyan }\end{array}$ & $\begin{array}{l}\text { Idyll of } \\
\text { Theocritus }\end{array}$ & $\begin{array}{l}\text { For soprano } \\
\text { and orchestra }\end{array}$ & 1956 & Audrey Nossaman \\
\hline Jean Barraqué & Nietzsche & Séquence & $\begin{array}{l}\text { Soprano and } \\
\text { orchestra }\end{array}$ & 1956 & Josephine Nendick \\
\hline Francis Poulenc & Jean Cocteau & $\begin{array}{l}\text { La Voix } \\
\text { humaine }\end{array}$ & $\begin{array}{l}\text { Tragédie } \\
\text { lyrique }\end{array}$ & 1959 & Denise Duval \\
\hline Francis Poulenc & Jean Cocteau & $\begin{array}{l}\text { La Dame de } \\
\text { Montecarlo }\end{array}$ & $\begin{array}{l}\text { Monologue } \\
\text { lyrique for } \\
\text { soprano \& } \\
\text { orchestra }\end{array}$ & 1961 & Denise Duval \\
\hline Milton Babbitt & $\begin{array}{l}\text { John Hollander, after } \\
\text { Ovid }\end{array}$ & Philomel & $\begin{array}{l}\text { Monodrama } \\
\text { for soprano, } \\
\text { recorded } \\
\text { soprano and } \\
\text { synthesizer }\end{array}$ & 1964 & Bethany Beardslee \\
\hline Sylvano Bussotti & After L. Labé & $\begin{array}{l}\text { La Passion } \\
\text { selon Sade }\end{array}$ & $\begin{array}{l}\text { Mystère de } \\
\text { chambre }\end{array}$ & 1965 & Cathy Berberian \\
\hline $\begin{array}{l}\text { Harrison } \\
\text { Birtwistle }\end{array}$ & Stephen Pruslin & Monodrama & Monodrama & 1967 & The Pierrot Players \\
\hline $\begin{array}{l}\text { Peter Maxwell } \\
\text { Davies }\end{array}$ & Richard Stow & $\begin{array}{l}\text { Eight Songs for } \\
\text { a Mad King }\end{array}$ & Monodrama & 1969 & Roy Hart \\
\hline Luciano Berio & Luciano Berio, et al. & $\begin{array}{l}\text { Melodrama } \\
\text { (from Opera) }\end{array}$ & $\begin{array}{l}\text { Melodrama, for } \\
\text { tenor and } \\
\text { eight } \\
\text { instruments }\end{array}$ & 1970 & Gerald English \\
\hline Hans Henze & Gaston Salvatore & $\begin{array}{l}\text { Der langwierige } \\
\text { Weg in die } \\
\text { Wohnung der } \\
\text { Natascha } \\
\text { Ungeheuer }\end{array}$ & Opera & 1971 & William Pearson \\
\hline Luciano Berio & $\begin{array}{l}\text { E. Sanguineti A. } \\
\text { Mosetti, L. Berio, [C. } \\
\text { Berberian] }\end{array}$ & Recital I & Music theater & 1972 & Cathy Berberian \\
\hline Carlisle Floyd & Carlisle Floyd & $\begin{array}{l}\text { Flower and } \\
\text { Hawk }\end{array}$ & $\begin{array}{l}\text { Monodrama } \\
\text { for soprano } \\
\text { solo }\end{array}$ & 1972 & Phyllis Curtin \\
\hline $\begin{array}{l}\text { George } \\
\text { Rochberg }\end{array}$ & $\begin{array}{l}\text { Robert Lowell, after } \\
\text { Racine }\end{array}$ & Phaedra & $\begin{array}{l}\text { Monodrama in } \\
\text { seven scenes }\end{array}$ & 1976 & Gene Rochberg \\
\hline $\begin{array}{l}\text { Jean Eichelberger } \\
\text { Ivey }\end{array}$ & & Testament of Eve & Monodrama & 1976 & Elaine Bonazzi \\
\hline $\begin{array}{l}\text { Elisabeth } \\
\text { Lutyens }\end{array}$ & $\begin{array}{l}\text { Extracts from the } \\
\text { letters of Van Gogh }\end{array}$ & $\begin{array}{l}\text {... like a window } \\
\text { op. } 109\end{array}$ & Music theatre & 1977 & $\begin{array}{l}\text { Freda Dowie, } \\
\text { London Voices }\end{array}$ \\
\hline Morton Feldman & Samuel Beckett & Neither & Opera & 1977 & $\begin{array}{l}\text { Martha } \\
\text { Hannemann }\end{array}$ \\
\hline Judith Weir & $\begin{array}{l}\text { Judith Weir, based on } \\
\text { Snorri Sturlson }\end{array}$ & $\begin{array}{l}\text { King Harald's } \\
\text { Saga }\end{array}$ & $\begin{array}{l}\text { Opera in three } \\
\text { acts }\end{array}$ & 1979 & $\begin{array}{l}\text { Jane Manning } \\
\text { (Commissioner) }\end{array}$ \\
\hline Heinz Holliger & Samuel Beckett & Not I & $\begin{array}{l}\text { Monodrama } \\
\text { for soprano } \\
\text { and tape }\end{array}$ & 1980 & Phillis Bryn-Julson \\
\hline $\begin{array}{l}\text { Peter Maxwell } \\
\text { Davies }\end{array}$ & Peter Maxwell Davies & The Medium & $\begin{array}{l}\text { Monodrama } \\
\text { for mezzo- } \\
\text { soprano solo }\end{array}$ & 1981 & Mary Thomas \\
\hline
\end{tabular}


Table 1. (Continued).

\begin{tabular}{|c|c|c|c|c|c|}
\hline Composer & Librettist & Title of work & Definition & Premiere & First Interpreter \\
\hline Elizabeth Vercoe & $\begin{array}{l}\text { Villon, Shakespeare, } \\
\text { Shaw, Twain et al. }\end{array}$ & $\begin{array}{l}\text { Herstory III: } \\
\text { Jehanne de } \\
\text { Lorraine }\end{array}$ & $\begin{array}{l}\text { Monodrama } \\
\text { for mezzo } \\
\text { soprano \& } \\
\text { piano }\end{array}$ & 1986 & Sharon Mabry \\
\hline Diamanda Galás & Diamanda Galás et al. & Insekta & $\begin{array}{l}\text { Electro- } \\
\text { acoustic } \\
\text { Monodrama }\end{array}$ & 1993 & Diamanda Galás \\
\hline Wolfgang Rihm & $\begin{array}{l}\text { "Schlusschor" von } \\
\text { Botho Strauß }\end{array}$ & Das Gehege & Monodrama & $\begin{array}{l}\text { 27th } \\
\text { October } \\
2006\end{array}$ & Gabriele Schnaut \\
\hline Louis Andriessen & After Anaïs Nin & Anä̈s Nin & $\begin{array}{l}\text { Monodrama } \\
\text { opera }\end{array}$ & 2009 & Cristina Zavalloni \\
\hline $\begin{array}{l}\text { Chaya } \\
\text { Czernowin }\end{array}$ & Wieland Hoban & Algae & $\begin{array}{l}\text { Monodrama } \\
\text { for bass and } \\
\text { piano }\end{array}$ & 2009 & Andreas Fischer \\
\hline Karja Saariaho & Amin Maalouf & Émilie & $\begin{array}{l}\text { Monodrama } \\
\text { for soprano }\end{array}$ & 2010 & Karita Mattila \\
\hline Unsuk Chin & $\begin{array}{l}\text { Unsuk Chin, based on } \\
\text { James Joyce, Homer }\end{array}$ & $\begin{array}{l}\text { Le silence des } \\
\text { sirènes }\end{array}$ & Monodrama & 2010 & Barbara Hannigan \\
\hline John Zorn & After Antonin Artaud & $\begin{array}{l}\text { La machine de } \\
\text { l'être }\end{array}$ & Monodrama & 2011 & $\begin{array}{l}\text { Amy Shoremount- } \\
\text { Obra }\end{array}$ \\
\hline
\end{tabular}

Note: Some of the information included in the table also appears in Jessica Payette, Seismographic Screams: Erwartung's Reverberations through Twentieth-Century Culture (Ph.D. Diss., Stanford University, 2008), 267-8.

century. The formal conventions governing the seamless alternation of lyrical and dynamic pieces, either sung in recitative or spoken-with or without instrumental accompaniment to sustain the dramatic flux in operatic scenes, which found its maximum expression in the codes of la solita formagradually became less rigid. Operatic drama progressively soared into representations of a fractured self, in overt critique and dialectic with the collective mores of society. Sandra Corse has particularly eviscerated the progressive shaping of modernist opera in its "revelation" of the self, tracking a parabola spanning late-nineteenth-century compositions from Richard Wagner and symbolist composers, to the more recent work of Olivier Messiaen and Philip Glass, through their treatment of subjectivity. ${ }^{10}$ In her excursus across modernist operas, Corse argues that opera has interpreted the interior world of an individual's subjective state more than any other performing art, and has offered a textual and orchestral counterpart to this inner world, contributing to the elaboration of selfhood in modernist aesthetics. ${ }^{11}$ The dramatic and musical depictions of the characters in modernist operas, in particular, as captured through their solo scenes, delineate a passage from a study of the self emanating from acts of decision and self-revelation to a progressive isolation and estrangement from the world. ${ }^{12}$ In this corpus of works, the

\footnotetext{
${ }^{10}$ Sandra Corse, Operatic Subjects (London: Associated University Presses, 2000).

${ }^{11}$ Corse, Operatic Subjects, 7-13.

${ }^{12}$ Corse, Operatic Subjects, 76-98.
} 
characters express a lack of individualism and deterioration of their selves, and appear as oppressed victims of their own mediocrity and failures through sporadic unconscious, yet overwhelming, epiphanies of their alienation. ${ }^{13}$ The relation with their musical depiction changes as well: the orchestral accompaniment often accentuates this split subjectivity by totally detaching and becoming other from the sung line.

Certainly a product of this sensitivity, twentieth-century monodrama, with its enhanced psychoanalytical quality, harkens back to multiple precursory structured representations of the female irrational: for example, those characterizing Baroque dramatic laments, classical cantatas scenicas, operatic solo scenes of the Romantic era, and the aforementioned late-nineteenth-century Victorian solo plays and dance, the latter nonetheless underpinned by a renewed and historically-determined inquiry into the female-body's kinetics. ${ }^{14}$ In particular, twentieth-century musical monodrama enlivens the aesthetics of the Renaissance and Baroque lament, a genre that also envisaged the reproduction of spontaneous spoken inflexions known as recitar cantando ${ }^{15}$ Laments were most often associated with female characters who engaged in streams of consciousness over loss or abandonment; these lamentations-which featured the vocal and histrionic prowess of cantatrices such as Francesca Caccini, Virginia Ramponi-Andreini ("La Florinda"), and Caterina Martinelli-became increasingly structured into rigid metric and harmonic grids, and were eventually emancipated as an independent semi-staged form. Most often, modernist musical monodrama reconnects with the aesthetics of loss, absence, and betrayal already extensively explored in seventeenth- and eighteenth-century solo performance, and recalls the practices and modes of the Baroque "speaking in song," in that the performer was invested of a creative role by improvising embellishments and cadenzas according to the principal affetti of the piece. In the same way, in fact, modernist monodrama progressively evolved as a crucible for experimentation concerning styles of singing not definable as operatic tout court, whereas its most recent examples give way to extreme embodiments of hysteria and a programmatic expansion of the boundaries of the extended vocal technique, as is true, for instance, of Juliana Snapper's work on vibrational practice and Diamanda Galás' performative virtuosity, to give just two examples. It is perhaps the centrality assigned to the soloist's agency that allows a spontaneous parallel to be drawn with modi and topoi appropriate to modernist sensitivity of twentieth-century monodrama, which were often the result of the composer's fascination with the skills of one specific performer.

\footnotetext{
${ }^{13}$ See for example Corse's appraisals of Wagner's Tristan und Isolde (Operatic Subjects, 53-64), and Debussy's Pelléas et Mélisande (Operatic Subjects, 82-8).

${ }^{14}$ Preston, Modernism's Mythic Pose, 21-28.

${ }^{15} \mathrm{~A}$ few examples of the genre are Monteverdi's II Lamento di Arianna (1607-1608), D'India's (1623) and Monteverdi's (c. 1620) II Lamento di Olimpia, and Haydn's Arianna a Naxos (1789). For voice and female solo performers, see for example Wendy Heller, Emblems of Eloquence: Opera and Women's Voices in SeventeenthCentury Venice (Berkeley, CA: University of California Press, 2004); Elizabeth Anderson, "Dancing Modernism: Ritual, Ecstasy and the Female Body," Literature and Theology 22, no. 3 (2008): 354-67; and Andrew Parker and Eve Kosofsky, eds., Performativity and Performance (New York: Routledge, 1995).
} 


\section{Creating the vocal role}

In most cases, the performer's agency impacted the compositional process of monodramas; for this reason, they represented unica not only in twentieth-century operatic and music-theater repertoire but also in the creative output of their respective composers: For example, La Voix humaine marked Poulenc's collaboration with Jean Cocteau and his lifetime fascination with Denise Duval's vocal and dramatic skills ${ }^{16}$; Peter Maxwell Davies' Eight Songs for a Mad King was composed for Roy Hart, a singer of exceptional vocal skill who could perform multiphonics ${ }^{17}$; Berio's Recital I (for Cathy) conceals in its homage to Cathy Berberian a dramatized manifesto of his views about music theater and vocality tailored to the performer to whom he entrusted his most significant early vocal output ${ }^{18}$; ultimately, Neither stemmed from the idiosyncratic collaboration between opera skeptics Morton Feldman and Samuel Beckett in response to a commission of the Teatro dell'Opera di Roma, and was created by Martha Hanneman, who had already been entrusted with previous vocal output from Feldman. ${ }^{19}$

In a work like Recital $I$, for instance, the subjective reflection of the dedicatee's self to the compositional texture of the work is intentionally

\footnotetext{
${ }^{16}$ Hervé Lacombe, Francis Poulenc (Paris: Fayard, 2013); Francis Poulenc, "Echo and Source," Selected Correspondence, 1915-1963, translated and edited by Sidney Buckland (London: Gollancz, 1991); Alban Ramaut, Francis Poulenc et la voix (Lyon, Symétrie: 2005); Denis Waleckx, "A Musical Confession: Poulenc, Cocteau and La Voix humaine," in Francis Poulenc: Music, Art, and Literature, translated and edited by Sidney Buckland and edited by Myriam Chimènes (Brookfield, VT: Ashgate, 1999).

${ }^{17}$ Sir Peter Maxwell Davies, preface to the score of Eight Songs for a Mad King (London: Boosey \& Hawkes, 1969), as quoted in Alan E. Williams, "Madness in the Music Theatre Works of Peter Maxwell Davies," Perspectives on New Music 38, no. 1 (2000): 81; Anne-May Krüger, "'If Something Else Works—Do It!': Peter Maxwell Davies' und Roy Hart's Eight Songs for a Mad King," Dissonanze (Basel, 2014): 23-30, http://www.dissonance.ch/en/archive/main_articles/958 (accessed May 17, 2017); T. Nikki Cesare, "'Like a Chained Man's Bruise': The Mediated Body in Eight Songs for a Mad King and Anatomy Theater," Theatre Journal 58, no. 3 (2006): 437-57; Ruud Welten, "I'm not III, I'm Nervous': Madness in the Music of Sir Peter Maxwell Davies," Tempo 196 (1996): 21-4.

${ }^{18}$ On the use of quotations in Recital I, see for example David Metzer, Quotations and Cultural Meaning in TwentiethCentury Music (Cambridge, UK: Cambridge University Press, 2003), 93-7; Clare Brady, "Musical Fragments in Berio and Berberian's Recital I (for Cathy): Questioning an Ontology of the Musical Work in Performance and ReCreation" (paper presented at the RMA Research Student Conference, University of Southampton, January 2013); Susan Youens, "Memory, Identity, and the Uses of the Past: Schubert and Luciano Berio's Recital I (for Cathy)," in Franz Schubert: Der Fortschrittliche? Analysen, Perspektiven, Fakten, edited by Erich Wolfgang Partsch (Tutzing, Germany: Hans Schneider, 1989), 231-47. A prospectus with the complete structure of the piece and all its musical quotations appears in Giovanni Cestino, When She Looks at Music: l'approccio performativo di Cathy Berberian attraverso lo studio delle sue partiture (Ph.D. Thesis, Università degli studi di Pavia, 2014), 175-8. My article, "Recital I: A Drama 'Through the Voice,"' is forthcoming in Twentieth-Century Music, while the chapter "Constructing Cathy: Intertextuality and Intersubjectivity in Recital I by Luciano Berio," in Intertextuality in Music Since 1900, edited by Paulo Castro and Federico Celestini, is in progress.

${ }^{19}$ Sebastian Claren, Neither: Die Musik Morton Feldmans (Hofheim, Germany: Wolke Verlag, 2000); Laurent Feneyreau, "Vanités et dramaturgies négatives," in Musique et dramaturgie: esthétique de la représentation au XXe siècle, edited by Laurent Feneyreau (Paris, France: Sorbonne, 2003), 731-808; "Morton Feldman et la clairière," paper delivered at the Festival d'automne à Paris (Paris: IRCAM, 2006); Catherine Laws, Headache Among the Overtones: Music in Beckett/Beckett in Music (Amsterdam: Rodopi, 2013); Catherine Laws, "FeldmanBeckett-Johns: Patterning, Memory and Subjectivity," in The Modernist Legacy: Essays on New Music, edited by Björn Heile (Aldershot, UK: Ashgate, 2009); Howard Skempton, "Beckett as a Librettist," Music and Musicians (May 1977): 5-6.
} 
conceived as a structural layer of the drama, and deployed to heighten the performative act. The aging diva who ends her hysterical journey into madness and a staged death resonates with dramatic topoi that Berberian had previously explored through her acquaintance with Monteverdi's laments and operatic repertoire-which persistently echo in the composition-and had championed in works like Visage (1961) and Sequenza III (1965), which, although not immediately conceived for the stage, could be righteously defined monodramatic exactly by virtue of the theatrical flair instituted by Berberian in their performance tradition. Recital $I$ is also interspersed with Berio's and Berberian's autobiographical hints, although the main inspiration for the work's protagonist, according to its dedicatee, was Maria Callas-her tragic vicissitude common to many opera singers. ${ }^{20}$ An emphasis on the abandoned lover also characterizes La Voix humaine, in which the protagonist engages in an intricate and intimate one-sided conversation with the external world through a telephone line. Denise Duval's participation in the creative process leading to the creation of La Voix humaine is manifested in Poulenc's correspondence and, more recently, confirmed by Duval in a video documentary recounting her contribution to the composition and mise en scène of the premiere, which was directed by Jean Cocteau himself. ${ }^{21}$ Duval recalls her demands, for changes in the vocal line in order to accommodate her tessitura, and her influence on the director's conception of the staging by her profoundly subjective interpretation of the protagonist. $^{22}$ Duval even convinced Poulenc to intervene with the structural cut of "the phase of the dog," as she believed that the scene detracted from the drama. ${ }^{23}$ Undoubtedly, the original characterization of the solo role in the opera reflected the conceptions of both the composer Poulenc and director and librettist Cocteau, and was conceived in accordance with Duval's physical and dramatic characteristics.

The freedom entrusted to the performer was to be registered either in the writing or in the performance tradition instituted by the creator of the role. For instance, in the performance guidelines of La Voix humaine, Poulenc stipulates:

The length of the held notes will depend of the performer's interpretation. They are so important, in this score. The conductor will decide on these in advance with the singer with accuracy. All the sung passages, without accompaniment, have a very free tempo, and are functional to the staging. One has to quickly shift from anguish to calm and viceversa. ${ }^{24}$

\footnotetext{
${ }^{20}$ Cathy Berberian, Ultime Parole, interview with Guido Salvetti, December 1982, in Cathy Berberian, Diagramma di Una Personalità Vocale, by Carlo Piccardi, Swiss-Italian Radio, in CD 3-3241, SCBe, PSS, accessed by courtesy.

${ }^{21}$ Dominique Delouche, La Muse et son poète: une évocation de Denise Duval et Francis Poulenc et "La Voix humaine" de Jean Cocteau et Francis Poulenc, video documentary, Les Films du Prieuré, Muzzik, 1999, 1 hour, 12 minutes.

${ }^{22}$ Delouche, La Muse et son poète.

${ }^{23}$ Waleckx, "A Musical Confession," 331-44.

${ }^{24}$ Francis Poulenc, Echo and Source: Selected Correspondence, 1915-1963, translated and edited by Sidney Buckland (London: Gollancz, 1991), 255.
} 
Because of the poietic role assigned to the soloist in the performative act, musical monodrama is a paradigmatic testimony to the limitations of the work as a written medium. In performance, the soloists' embodied voice transcends the conventional representation of the abstract prolongation of the composer's voice to situate itself as the subjective territory of the soloists' agency, enacting an immersive dramatic space through their physical response; the soloists and their personae are invested with a responsibility unprecedented in other operatic contexts.

To provide another example, in a letter to Berberian, Berio instructs the singer to engage in a seamless vocal performance of Recital $I$, and rejects her suggestion that the printed text be made available to the audience to elicit surprise effects. ${ }^{25}$ Berio assigns an improvisatory quality to the monologue delivered by the singer, and a significant role to her enacted immanent synthesis of music and text. Similarly, Peter Maxwell Davies, although acknowledging Roy Hart's contribution to the creative process leading to Eight Songs for a Mad King, specifies the possibility of the vocalist tailoring their interpretation in accordance with their performance strengths: "I just left it. And they [other interpreters] can cope with it as best they can. And they do cope in a way. ... Of course, they can't do his multiphonics." But there are plenty of other things that they can do, as we have learned. ${ }^{26}$ Maxwell Davies in fact leaves future performers free to interpret George III's madness in accordance with their own bodily tessitura and vocal spectrum, aware of the impossibility of reproducing the unique technical skills of the first interpreter.

In musical monodramas, while in charge of the dramatic momentum the singers' embodied voices represent the living utterance of the interaction of presence (the protagonist and her/his monologue) and absence (the absent character/s and situations about which the protagonist is singing). The singers also have to negotiate with tight tempi and the sonic challenges of a musical conundrum, modulating their voices according to the dramatic rhythms of a script simultaneously interwoven with multiple acoustic forces and stimuli. The role of the orchestra is indeed complex and examplespecific: Often, the instrumental ensemble dialogues with the soloist and participates in recreating the tinta of the dramatic action; however, depending on the dramatic circumstances and the language adopted by the composer, it works as an invisible partner with an antagonist to the character, and comments on or suggests unspoken feelings and unseen circumstances surrounding the action suggested by the protagonist's inner monologue. Nevertheless, the orchestra adds another form of resistance to the singer's

\footnotetext{
${ }^{25}$ Luciano Berio, letter to Cathy Berberian, Korrespondenz, Sammlung Luciano Berio, Paul Sacher Stiftung (SLB, PSS). Accessed by courtesy.

${ }^{26}$ Krüger, "'If Something Else Works-Do It!'," 23.
} 
delivery, whose embodiment against and within these multiple forces establishes a successful synaesthesia the more she/he endows the performance with an immersive quality. In musical monodramas, therefore, the solo performers' engagement is demanding in terms of bodily presence, performance intelligence, memorization, and vocal skills. They ultimately sustain physically and psychologically the condition of being the only visible purveyors of the dramatic action. This is manifest, for instance, in Neither, in which Beckett and Feldman's abstract conceptions of the work-reverberating into its "ghostly" quality-clashes with the actual embodiment of the role, which remains vocally and physically straining. The female voice is here "technologically" deployed to evoke existentialist amazement and prolonged elusiveness of the present. Yet the ways in which this "betweeness" is substantiated through voice is vitally dependent on its actual enactment, and ultimately on the unique embodied engagement of the solo performer. Neither is a tour de force for the singing protagonist, who will have to support pianissimo dynamics on a very high register throughout sustained phrasing, and with a deliberate lack of articulation in the delivery, thus accurately avoiding every possible form of climatic self-enjoyment. ${ }^{27}$

In the case of La Voix humaine, Poulenc aimed to create a unifying procedure among different thematic cells, so that the end result of the dialectic between sonic and textual on one side, and silent and subtextual on the other, would not result in fragmentation. For instance, the pacing and content of the answers provided by the invisible interlocutor $(\mathrm{He})$ are rendered by the length and intensity of pauses and rests delivered with notable performance freedom by the protagonist; in some cases, however, his reactions to the protagonist's statements are translated into a short instrumental counterpart (see Example 1). ${ }^{28}$

This short rhythmic pattern, which also appears in the opening bars of the opera, is a vigorous reflection of the invisible-character's feelings, and provides contrast to the languid lines of the protagonist, whose pathetic expectations are to be deluded. The motif returns at the intrusion of the switchboard lady, betraying the interlocutor's disappointment, and when he is finally caught lying by Elle, however unwilling he is to admit it (see Example 2).

The audible text the soloist delivers is not the only one perceived by the audience; most of all, the performer has to convey the impending ellipses produced by the absent characters using only her own dynamic body, the inflections of her voice, the duration of her pauses. In the next example from

\footnotetext{
${ }^{27}$ Francesca Placanica, "The Quest for Voice: En-Gendering Neither" (paper delivered at the 14th Annual Plenary Conference of the Society for Musicology in Ireland, Dublin City University, Dublin, June 11, 2016).

${ }^{28}$ This thematic cell is defined "Exasperated waiting" in the analysis by Denis Walecx. Walecx also highlights the central role of the orchestra in the characterization of the drama; however, it only marginally approaches the central role of the soprano; Waleckx, "A Musical Confession," 336.
} 


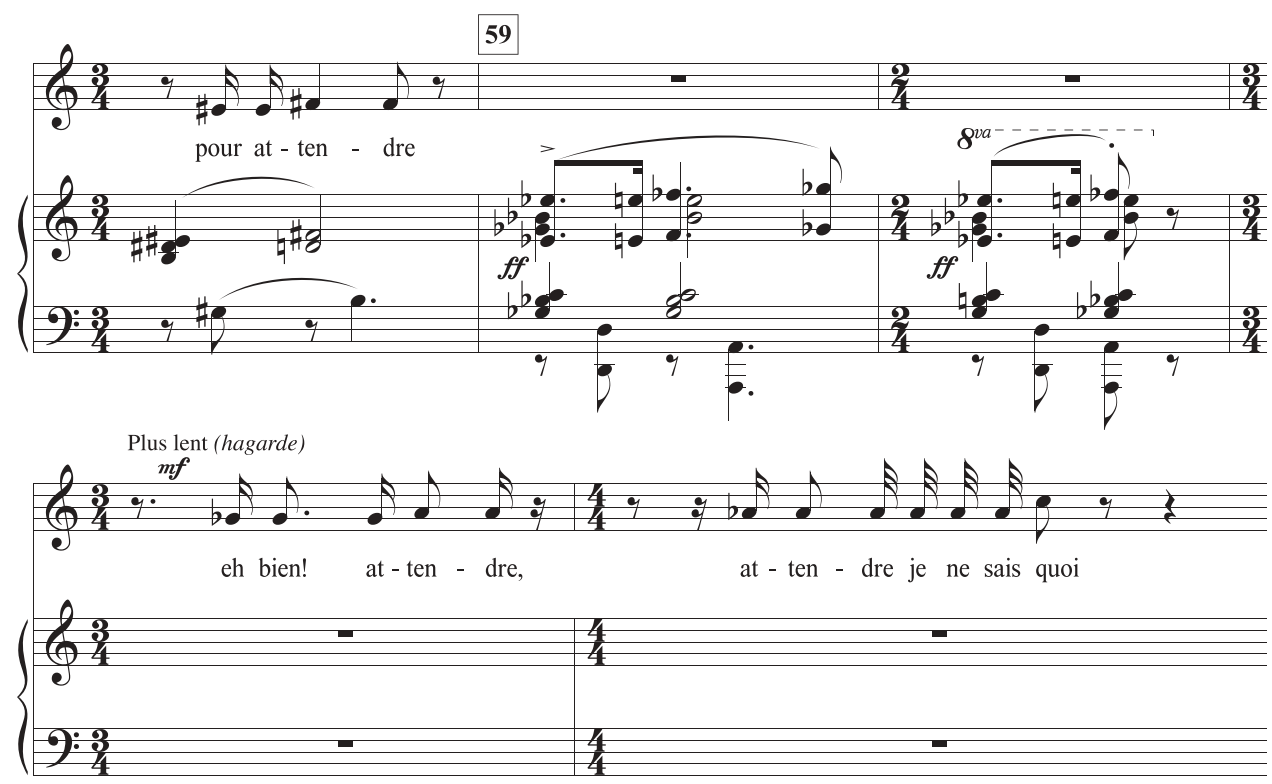

Example 1. Francis Poulenc, La Voix humaine, vocal score, p. 35, bars 407-11. Copyright @ 1958 by Sté Ame des Editions Ricordi. @ Ricordi Paris - Paris, France. All rights reserved. Reproduced by kind permission of Hal Leonard MGB S.R.L.-www.halleonardmgb.com.

La Voix humaine (see Example 3), the audience is empathically drawn into a sensual reflection by the protagonist, soon disrupted by the invasive sounds coming from the external world, possibly a jazz orchestra playing in the background of the restaurant from where the lover is calling Elle and perpetrating his lie concerning his whereabouts. The alternation between orchestra and voice produces in the listener conflicting dramatic effects.

Through the illusion created by the singer's embodiment and impersonation, audience members are called upon to imagine the more or less explicit vocal reverberations of the text. "J'ai des yeux à la place des oreilles," says Elle in La Voix humaine as she imagines her lover's doings, voicing the memory of their day-to-day life (see Example 4).

In fact, this is also the condition of the spectators as they reconstruct through gaze and hearing text and subtext a whole imaginary world molded by the performer's sung speech act. By "doing things with her voice," the performer not only brings a fictional character to life: She also exhibits before the spectator's eyes the unique vocabulary of her performative persona through the subjective unfolding of her body in time and space. In La Voix humaine, for instance, the audience's gaze and hearing necessarily focuses on the one protagonist and on her continued pathetic denial; however, impressions of the places and ways of the lover's lying also emerge through the music-silence-text weaving. This multi-sensorial illusion nurtures the audience's perspective, leading it to a panoptical experience. Through the body 

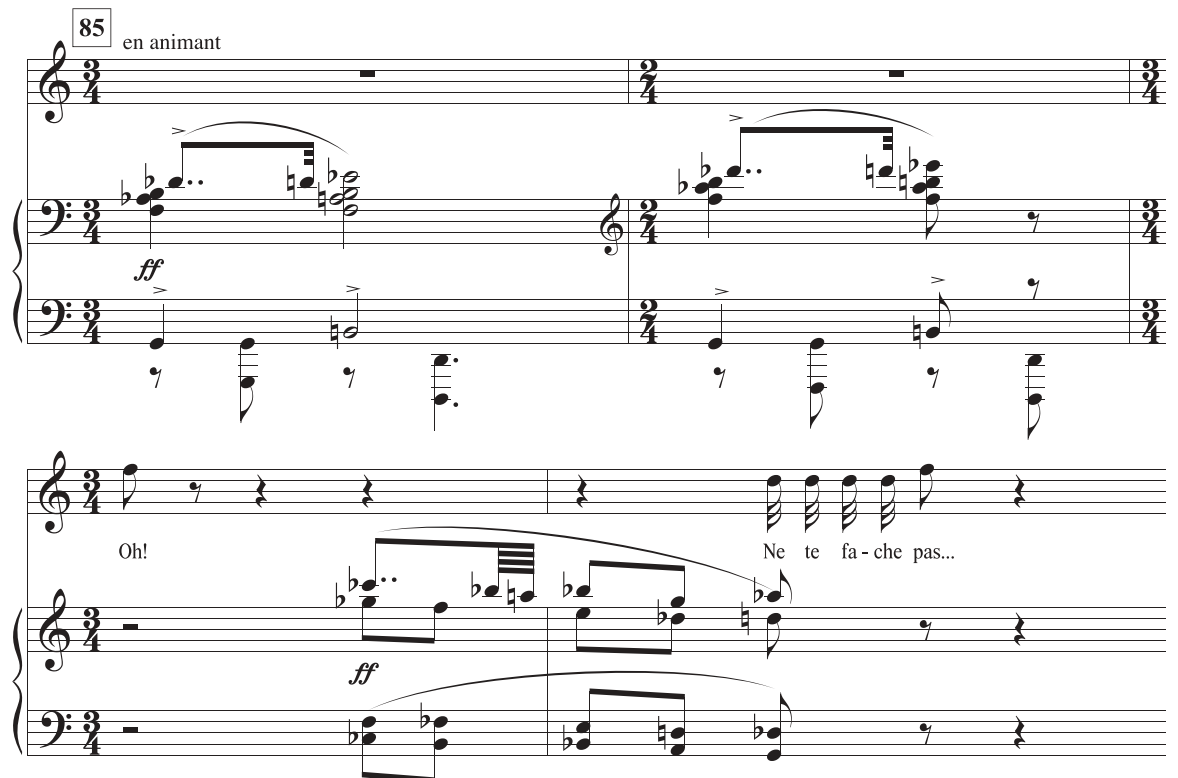

Example 2. Francis Poulenc, La Voix humaine, vocal score, p. 56, bars 621-4. Copyright @ 1958 by Sté Ame des Editions Ricordi. $\odot$ Ricordi Paris - Paris, France. All rights reserved. Reproduced by kind permission of Hal Leonard MGB S.R.L.- www.halleonardmgb.com.
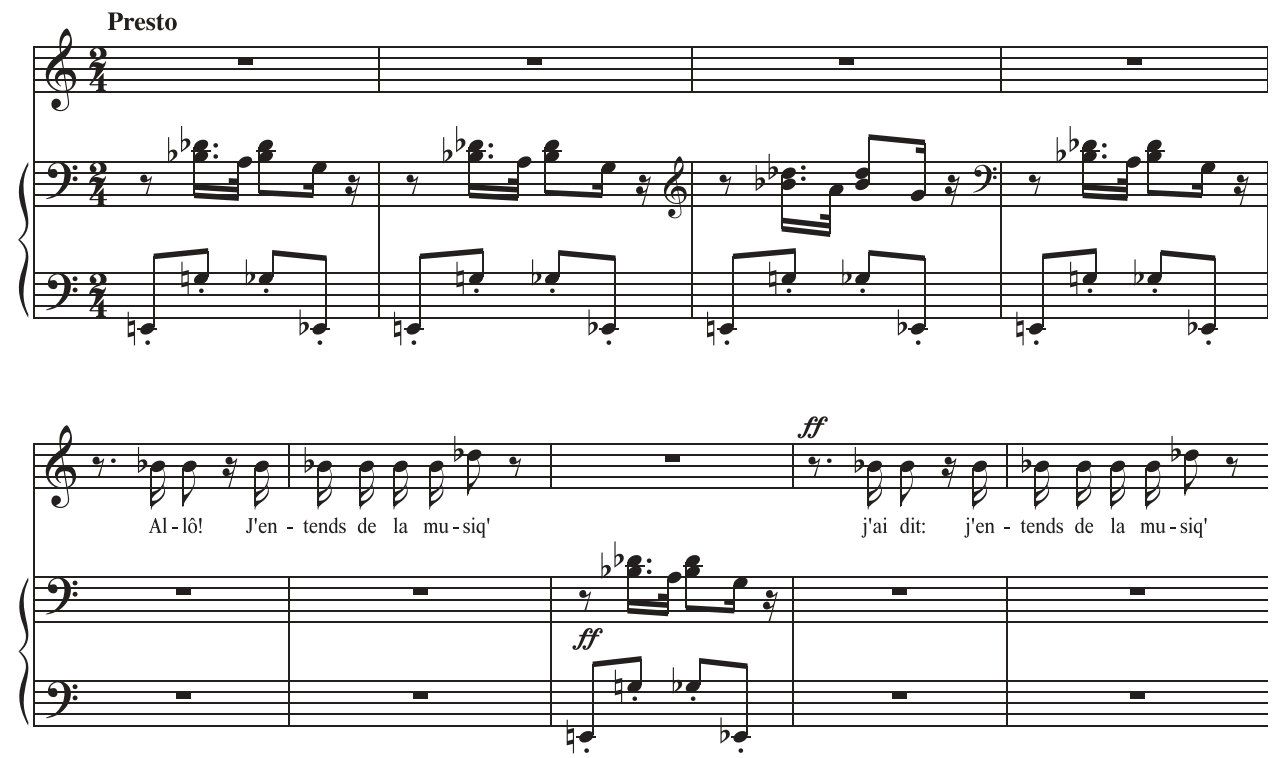

Example 3. Francis Poulenc, La Voix humaine, vocal score, p. 43, bars 485-93. Copyright @ 1958 by Sté Ame des Editions Ricordi. $\odot$ Ricordi Paris - Paris, France. All rights reserved. Reproduced by kind permission of Hal Leonard MGB S.R.L.- www.halleonardmgb.com. 


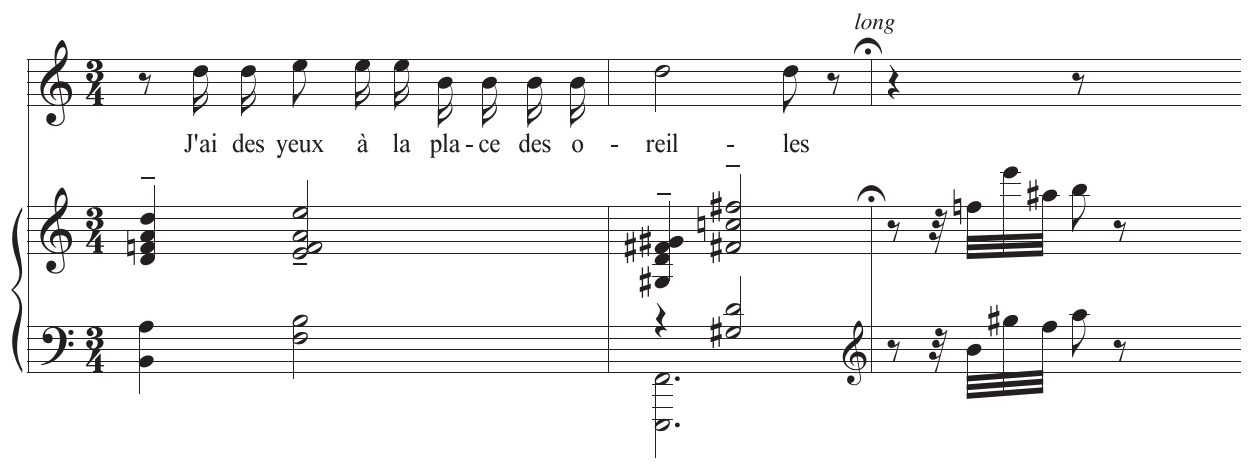

Example 4. Francis Poulenc, La Voix humaine, vocal score, pp. 20-21, bars 246-7. Copyright ( 1958 by Sté Ame des Editions Ricordi. ( $)$ Ricordi Paris - Paris, France. All rights reserved. Reproduced by kind permission of Hal Leonard MGB S.R.L.—www.halleonardmgb.com.

and voice of the performer and the orchestral responses, the spectator becomes the only agent able to entirely grasp the dramatic trajectory. The audience's "all-seeing eye" presupposes the rewriting authority of the audience's imaginative projection and desire over the solo performer. ${ }^{29}$

\section{Musical monodrama and contemporary staging}

Monodramas maintain a quite consistent performance tradition. More than any other vocal genre, their appearance into operatic programs seems almost apologetic: Their production needs justification, an overarching theme, some kind of ideological blanket to spare the audience the apparent performative shortage that the work seems to bring with it. From the consumer's point of view, in fact, one monodrama alone is too short to fill an entire evening at the opera, and too "economical" to engross the typical opera lover. Operagoers would not attend Schoenberg's Erwartung without expecting to see Bartók's Bluebeard's Castle on the same program; for a long while, Poulenc's La Voix humaine was paired with Giancarlo Menotti's The Telephone; and Feldman's Neither opened alongside Stravinsky's Feux d'artifice, Satie's Mercure, and Calder's ballet Work in Progress, and in 2015 appeared merged with Beckett's spoken play Footfalls, contemporary with the composition of the opera. This pre-packed framework-in which the already-established kinship between the psychoanalytical quality of the programmed works is favored over any other aspect-impacts the reception and position of these compositions within the twentieth-century musical canon, allowing little room for further and unbiased appraisal.

\footnotetext{
${ }^{29}$ The notion of the "all-seeing eye" is drawn from Michel Foucault's Discipline \& Punish: The Birth of the Prison (New York: Vintage, 1979), in particular the section entitled "Panopticism," 195-230.
} 
On the other hand, since the language of these works is in most cases far from accommodating to conventional audience tastes, producers feel compelled to compensate with a staged radicalization of the identity of the solo performer. This is possible because the staging of a monodrama with a female protagonist triggers an entirely different set of expectations. A solitary performer-unrivalled-challenges both the audience and the stage, and the way in which she embodies this challenge necessarily has to do with her identity or, to put it crudely, her marketability. For instance, many productions of La Voix humaine have been the testing ground both for rising stars and established sopranos and mezzo-sopranos, who are called to field-test their absolute presence in engaging with such an intense musical text. Verismo diva Magda Olivero's 1970 performance of La Voix humaine at La Fenice has all the character and volume of a Puccinian opera. ${ }^{30}$ It is worth mentioning that Magda Olivero chose La Voix humaine as a vehicle for her farewell to the stage in 1981. Renata Scotto, undisputed diva of Italian belcanto, confirmed her vocal and dramatic credentials with her 1996 interpretation. No longer in her prime (she was at that time in her sixties), Scotto conquers the scene with her confident delivery, but her statuesque stage presence fails to observe the rendition of the young and mediocre victim wanted by Cocteau. ${ }^{31}$ In other cases, the performer's body and synaesthetic vocal eroticism is radicalized by the performances of sopranos Carole Farley, Julia Migenes, and Camille Zamora, all of whom explore either fierce or subtle sensuality both in their live performances and subsequent video transpositions. ${ }^{32}$

This trend in production seems to be telling of a virtual "impasse": The empowerment of a performer's operatic prowess responds to the limited breadth of the work and its shortage of melodramatic action. Most recently this attitude seems to have invested the actual theatrical structure of the work, denaturalizing its solipsistic nature through the juxtaposition of "artificial" characters on stage. This, for instance, was the case with the 2014 production of Samuel Beckett and Morton Feldman's opera Neither, directed by Katie Mitchell for the Berlin Staatsoper, which highlighted the contemporary genesis of the monologue Footfalls and of the opera Neither by staging an interpolated rendition of the two monologues. ${ }^{33}$ In addition

\footnotetext{
${ }^{30}$ Magda Olivero in La Voix humaine, Orchestra of the Teatro "La Fenice," conductor Nicola Rescigno (Venice, 3rd May 1970), https://www.youtube.com/watch?v=Iwcwe0BVt_0 (accessed June 1, 2017).

${ }^{31}$ Renata Scotto, La Voix humaine, Symphonic Orchestra of Teatro del Liceu, conductor Josep Pons (Barcelona, 1996), https://www.youtube.com/watch?v=9BwbIVd8TXs\&t=4s (accessed June 1, 2017); Jean Cocteau, La Voix humaine, performance notes (Paris, France: Ricordi, 1959), 1.

${ }^{32}$ Carole Farley, La Voix humaine, Scottish Chamber Orchestra, conductor Jose Serebrier, DVD (2006); Julia Migenes, La Voix humaine, a film by Peter Medak, Orchestre National De France, conductor Georges Prêtre, DVD (2009); Camille Zamora, La Voix humaine, Auckland Chamber Orchestra, conductor Peter Scholes, director Raymond Hawthorne, Auckland Opera (2011), https://www.youtube.com/results?search_query=camille+zamora+voix thumaine (accessed June 1, 2017).

${ }^{33}$ Morton Feldman and Samuel Beckett, Neither/Footfalls, conductor François-Xavier Roth, director Katie Mitchell, soprano Laura Aikin, actress Julia Wieninger, and other performers, Staatsoper (Berlin, 2014). Interview with Katie Mitchell, https://www.youtube.com/watch?v=yOXN2tLN11I (accessed June 1, 2017).
} 
Mitchell chose to introduce more characters to the stage, representing silent avatars of the singing protagonist, thus completely modifying the balance and scope of the opera. The same effect was realized in La Voix humaine, directed by Krzysztof Warlikowski and starring Barbara Hannigan in the role of Elle in a 2015 double-bill production including Bluebeard's Castle by Béla Bartók. Lui, the invisible male character supposed to be evoked only in Elle's singing, appears in the background and, though deprived of any sonic utterance, heavily intrudes and interacts on stage until the final coup de théatre, where the stage is shaken by the appearance of a revolver and subsequent blood. ${ }^{34}$ A similar heightened outcome is achieved in Robert Lepage's 2015 rendition of Erwartung for the Canadian Opera Company with the apparition of the psychiatrist, actor Mark Johnson. ${ }^{35}$ Alain Lagarde and Matthew Jocelyn's Opéra Hamburg staging of Erwartung is populated by a few supernumeraries, and ends with the protagonist executed in the electric chair. It is perhaps fitting to mention that the performance was part of an evening named Trilogie der Frauen, which also featured Wolfgang Rihm's Gehege and the premiere of Oscar Strasnoys' Le Bal on the same night, in March 2009. ${ }^{36}$

Again, these performative excesses seem to be the fruit of some sort of deadlock. The question is whether the sources of this virtual "impasse" arise in response to the limited breadth and estranging musical language of these works, or whether they are dictated by the unique gendered utterance of the soloist. Why is the one singing performer not enough to fill the scene? What kind of audiences are those productions appealing to? Are these attempts a way to bring monodrama closer to a more conventional operatic, or even melodramatic, setting? And, if this is the case, is modernist monodrama ultimately separate from opera?

\footnotetext{
${ }^{34}$ Francis Poulenc, La Voix humaine, conductor Esa-Pekka Salonen, stage direction Krzysztof Warlikowski, soprano Barbara Hannigan, Opéra National (Paris, 2015), trailer at https://www.youtube.com/watch?v=SBPGCymHS_w], full recording at https://www.youtube.com/watch?v=4KMByAEPLOk; interview with Hannigan at https://www. youtube.com/watch?v=H08k7PQTIz0 (all accessed June 1, 2017).

${ }^{35}$ Béla Bartók/Arnold Schoenberg, Bluebeard's Castle/Erwartung, directed by Robert Lepage, Canadian Opera Company, Hummingbird Centre (Toronto: September 21-October 6, 2001), http://www.stage-door.com/ Theatre/2001/Entries/2001/10/6_Bluebeards_Castle__Erwartung.html (accessed June 1, 2017); Richard Ouzounian, "Bluebeard's Castle/Erwartung Still has the Magic: Review of Arnold Schoenberg, Erwartung, Conductor Johannes Debus, Director Robert Lepage, Mezzo-Zoprano Krisztina Szabó, Actor Mark Johnson, Canadian Opera Company, Toronto, 2015," Toronto Star, May 6, 2015, https://www.thestar.com/entertainment/ music/2015/05/06/bluebeards-castleerwartung-still-has-the-magic-review.html, trailer at https://www.youtube. com/watch?v=-5Ro1EKA09s (accessed June 1, 2017).

36“"Review: 'Trilogie der Frauen' an der Hamburger Staatsoper," Augsburger Allgemeine, March 8, 2010, http://www. augsburger-allgemeine.de/kultur/Trilogie-der-Frauen-an-der-Hamburger-Staatsoper-id7431706-amp.html (accessed June 1, 2017); Georges Briscot, "What it Feels like for a Girl," Trilogie der Frauen, Erwartung, Schoenberg / Le Bal, Strasnoy / Das Gehege, Rihm, Hamburgische Staatsoper, Operaticus, March 7, 2010, http://www. operaticus.com/trilogie_der_frauen_hamburg_staatsoper_review.html (accessed June 1, 2017); Tom R. Schulz, "Trilogie der Frauen: Hübsch hysterisch haben Sie's hier," Hamburger Abendblat, 9th March 2010, http://www. abendblatt.de/kultur-live/article107659320/Trilogie-der-Frauen-Huebsch-hysterisch-haben-Sies-hier.html; (accessed June 1, 2017).
} 


\section{"Monodramatic impasses" and "operatic scandals"}

The issue of the performer's body in opera performance has been discussed somewhat marginally in the past, but a few eminent scholars are currently highlighting new perspectives. Lately Nina Sun Eidsheim has framed the voice's materiality as an experience shared between performer and listener, bringing to light examples deriving from embodied practice. ${ }^{37}$ Nevertheless, I still find Michelle Duncan's views compelling. According to Duncan, opera studies are limited by a focus on an "ideal" real performance, a text that usually refers to a specific utterance emanating from the written work or from an operatic production, and completely neglecting its materiality: "Voice slips into a position of silent alterity, strangely disenfranchised from corporeality and unable to resound."38 This vision, argues Duncan, completely neglects the creative agency of the performer in the interpretation, as well as the inter-subjective forces at work to sustain the work's immanence. If this is true for multi-character operas, monodrama represents the epitome of this body-centered narrative. The singer's performing persona has morphogenetic impact, being her utterances unmediated by interaction with other actors and fully embedded in the musical and dramatic texture of the music. The performance of a monodrama relies uniquely on the embodied synthesis of voice, body, and presence of an intelligent and creative Ur-medium, which enacts its speech act as a compelling additional text. ${ }^{39} \mathrm{~A}$ speech act cannot be an act without the body, and this principle, transferred to the staged monologue, fully incarnates the poietic potential of the embodied voice in performance. The solo performer not only sings but does something that transcends the composer's prescription, simply by virtue of the performative flux conveyed solely by her persona. The speech act frames the utterances into a communicative dynamic; even if alone on stage, the performer triggers mechanisms of empathy with the audience. Adriana Cavarero refers to the primacy of uniqueness to the interaction of sound and voice as phoné, ${ }^{40}$ and reassigns the voice to the body and to the uniqueness of the utterer: ${ }^{41}$ "The emitted voice always comes out into the world, and every man within earshot is struck by it." ${ }^{\text {"42 }}$ Her ontology of uniqueness affirms that "the voice is always unique, and the ear recognizes as such the emitted voice." 43 One can very easily deduce the implications for vocal music of this concept: Every interpretation of song by a different performer, or by the same performer in different contexts, is unique. Such consideration may not be particularly revealing: After all, opera audiences have developed sufficient knowledge to discard or retain

\footnotetext{
${ }^{37}$ Nina Sun Eidsheim, Sensing Sound: Singing and Listening as Vibrational Practice (Durham, NC: Duke University Press, 2015). I intend to develop theoretical discussion of this theory in my future work.

${ }^{38}$ Eidsheim, Sensing Sound, 285.

${ }^{39}$ Eidsheim, Sensing Sound, 289.

${ }^{40}$ Adriana Cavarero, For More than One Voice: Towards a Philosophy of Vocal Expression (Stanford, CA: Stanford University Press, 2005), 173-82.

${ }^{41}$ Cavarero, "Introduction," For More than One Voice, 1-16.

${ }^{42}$ Cavarero, "A vocal ontology of uniqueness," For More than One Voice, 178.

${ }^{43}$ Cavarero, "A vocal ontology of uniqueness," For More than One Voice, 173-82: 177.
} 
one utterance over another and, in most cases, favor a particular "unique utterance" or interpretation of musical materials. The "carnal" nature of twentiethcentury musical monodrama therefore springs from a synaesthetic quality that bestows a poietic role on the performer. At the same time, as Duncan points out, "Opera studies have neglected the immanency of the voice as embedded in the singer's body, unless they became the visible of erotic desire incarnated on stage and offered to the spectator." 44

Monodrama in its performative immanence therefore emphasizes the "scandalous" aurality and materiality of the body as an emanation of the spectator's desire, which current mechanisms of production seem to favor. Hence, informed by the audience's all-seeing eye, the staging of a monodrama capitalizes on the performer's marketable credentials. This is true for many of the contemporary versions of La Voix humaine, where the interpretation of Elle becomes a calling card of sorts for the singer's marketed identity. Possibly this "scandalous" materiality is perceived as insufficient at times, almost as an embarrassing shortfall that needs to be redressed by opulent staging and additional characters, as in the above-mentioned Warlikowski version of La Voix humaine. The staging incorporates a dramatic refueling produced by exogenous components: superimposed interactions, exits and entrances, supernumeraries, blood, silent commentators.

Such performative excesses are symptoms of a tradition that has avoided the "impasse" of drama engendered through the body to serve the crafted musical component, an aesthetic that according to Cavarero spans the world of music theater and, likewise, the established operatic repertoire, despite the open revolt against the kitsch of opera advocated by music-theater composers such as Luciano Berio, Sylvano Bussotti, Morton Feldman, and John Zorn. ${ }^{45}$ Mladen Dolar describes the unsolvable tension between words and music as intrinsic to opera since its origins, the old good "dilemma of prima la musica, e poi le parole." 46 It is perhaps noteworthy that, while in the prose-theater repertoire, monologues are evenly distributed between female and male solos (think of the various kings, common men and heroes that populate the twentieth-century stage ${ }^{47}$ ), musical-monologue settings lie mostly in the hands of female protagonists, whose feminine hysterical impressions

\footnotetext{
${ }^{44}$ Duncan, "The Operatic Scandal of the Singing Body," 285.

${ }^{45}$ Sylvano Bussotti, "Allegoria nei fatti" ("Allegory actually," in my translation), in Cathy Berberian: Pioneer of Contemporary Vocality, edited by Pamela Karantonis, Francesca Placanica, Anne Sivuoja-Kauppala, and Pieter Verstraete (Farnham, UK: Ashgate, 2014), 223-4. Feldman's concept of the musical settings of texts has been discussed widely by the composer himself, and extensively reported by, among others, Sebastian Claren in Neither: Die Musik Morton Feldmans (Hofheim, Germany: Wolke Verlag, 2000) and more recently by Catherine Laws in Headache Among the Overtones: Music in Beckett/Beckett in Music (Amsterdam: Rodopi, 2014), 255-8. John Zorn's reluctance towards the literary text is expressed in a recent interview: Steve Dollar, "An Opera Drawn from Art," New York Times, March 19, 2011, http://www.wsj.com/articles/SB10001424052748704608504576208672316884018 (accessed November 13, 2015).

${ }^{46}$ Mladen Dolar, A Voice and Nothing More (Cambridge, MA: MIT Press, 2006), 30.

${ }^{47}$ See Jo Bonney, Extreme Exposure: An Anthology of Solo Performance Texts from the Twentieth Century, 1st ed. (New York: Theatre Communications Group, 1999), 450.
} 
populate the musical repertoire of the twentieth and twenty-first centuries. ${ }^{48}$ This very basic factual observation finds interesting resonance in Cavarero's discussion:

As the myth of the Sirens teaches us, song is heard as naturally feminine, just as speech is naturally masculine. Destined to substantiate themselves in the semantic, men's voices tend to disappear in the mute labor of the mind, or thought. By modulating themselves in song, on the other hand, women's voices come to show their authentic substance-namely, the passionate rhythms of the body from which the voice flows. ${ }^{49}$

This actual separation of roles seems to be reflected in the monologue productions of twentieth-century theater, in which man (in monologues) speaks, woman (in musical monodrama) sings. As Dolar puts it, "The voice beyond sense is self-evidently equated with femininity, whereas the text, the instance of signification, is in this simple paradigmatic opposition on the side of masculinity." $"$ This view of the "voice beyond sense" is indeed the quality assigned to the fractured musical syntax of these staged vocal works, which are in most cases a representation of a stream of consciousness, often conveyed beyond the sonic. The singing woman's hysterical conditions are reflected in the way they express themselves: These characters mumble, mutter, whisper, scream, and suffer through idioms that continuously elude or evoke their self-assertion, as is the case for Erwartung, the disrupted telephone conversation musically depicted in La Voix humaine, or the aphasia depicted in Lied, the final section of Recital I. These two types of monologues therefore seem to incarnate the dichotomy between logos and voice. I would also add that musical writing, intended as the composer's voice, is the man's domain, while the musical performance of the dramaalthough the masculine and rational re-elaboration of the female irrationalis the realm of the female singer, as noted by Cavarero:

In this sense, the woman who sings is always a Siren, or a creature of pleasure, extraneous to the domestic order of daughter and wife. The female singing voice cannot be domesticated; it disturbs the system of reason by leading elsewhere. Potentially lethal, it pushes pleasure to the limits of what is bearable. ${ }^{51}$

Although this separation is true for most of the twentieth-century repertoire (exceptions to this are, for instance, Maxwell Davies' Eight Songs for a Mad King and Berio's Melodrama, which emancipated itself from later versions of Opera), during the second half of the century a new trend is evident. In

\footnotetext{
${ }^{48}$ For example, Feldman's Neither is scored for soprano, as are Schoenberg's Erwartung, Poulenc's La Voix humaine, and Zorn's La machine de l'être, while Peter Maxwell-Davies' The Medium and Luciano Berio's Recital I are for mezzo-soprano. We should, however, recall Peter Maxwell-Davies' For a Mad King, scored for baritone.

${ }^{49}$ Cavarero, For More than One Voice, 118.

${ }^{50}$ Dolar, A Voice and Nothing More, 43.

${ }^{51}$ Cavarero, For More than One Voice, 118.
} 
avant-garde vocal writing, the lingua franca inherited by the stylistic and technical conventions related to operatic writing dissolved in favor of multiple singing idioms that varied not only from composer to composer but between the works of a single composer. Against such a backdrop, the role and voice of each performer became gradually and almost spontaneously charged with a different expectation. This process, reaching its extreme in the age of electro-acoustic composition, developed into collaborative relationships, and resulted in more or less openly acknowledged co-authorship of many works. Such interactive relationships were pursued through the creation of the works and their earliest performances, at which point the spontaneous performance creativity of the singer suggested, or extemporarily introduced, modifications to the text to be embedded in successive versions of the written score and its performance indications. The healthy evolution of this process in the twenty-first century was the forging of an entire trend of performer/composers or well-acknowledged forms of authorial collaboration. In the early twenty-first century, female composers wrote musical monodramas precisely to critically address stock representations of gendered viscerality and psychoanalytic introspection, thus providing a gendered response to an entire compositional mythology that was until then exclusively handled by male composers. ${ }^{52}$

Denting the psychoanalytic tradition of the hysterical and distressed women, Unsuk Chin's Le Silence des Sirènes (2010) fashions on Barbara Hannigan's performance persona a synthesis of both Homer's and Joyce's writings on the myth of sirens. The collaborative process leading to the premiere of the work is described by both the composer and the performer as an open process, in which orchestra, director, and performer concocted the final version of the work in collaboration with the composer. In the conception of the work, Chin left remarkable room for her interpreter's rendition of the dramatic development and subsequent vocal improvisation. The resulting impersonation imbues the score with irony and color in ways that affect the characterization of the protagonist and the substance itself of the work. ${ }^{53}$

In explaining the genesis of the monodrama Émilie as a privileged format consciously chosen so as to display Karita Mattila's performative skills, Kaija Saariaho compares her view of her character and the ways the female protagonist is traditionally portrayed in the historical monodramatic repertoire, citing

\footnotetext{
${ }^{52}$ See for instance, Elisabeth Lutyens' ...like a window op. 109, Judith Weir's King Harald's Saga, Elizabeth Vercoe's Herstory III: Jehanne de Lorraine, and Diamanda Galás' Insekta.

${ }^{53}$ Unsuk Chin and Maris Gothoni, "Thoughts on Le Silence des Sirènes," 97-110; Unsuk Chin, Le Silence des Sirènes, excerpts from the score, in Unsuk Chin, in "2014 Roche Commissions," Lucerne Music Festival (Reinach: Stans, 2014), 111-18; Unsuk Chin and Barbara Hannigan, Unsuk Chin and Barbara Hannigan about "Le Silence des Sirènes," Berliner Philarmoniker, May 26, 2015, at 10 minutes and 31 seconds, https://www.digitalconcerthall.com/ en/interview/20450-4 (accessed April 29, 2017).
} 
examples from La Voix humaine and Erwartung. ${ }^{54}$ By choosing to narrate the life and work of scientist Émilie du Châtelet and her views about love and relationships, Saariaho intentionally subverts the conventional topos of the heroine victimized and objectified by her lover, and empowers the protagonist as the only maker of her own destiny, both in her private and public life. Both composers reference their vocalists, not only highlighting their "instrumental" qualities but also their scenic and human gamut, and value their contribution and authorial drive towards the work as the opportunity to draw on their creative personalities as additional components to the composition.

Although drawing comparisons and analogies with the way male masters deployed their "muses" would drift away from my current objectives, these examples show that the making of monodramas takes place within a special social framework, which is unparalleled in any other forms of opera. If nothing else, the comparison with current models of collaboration demonstrates that the creative process leading to the composition of such works is horizontal, to say the least. As evidenced in contemporary accounts of composers with regard to their criteria and choices for their solo female interpreter, the relationship between composer and performer is a two-way process. The solo interpreter's skills and qualities often trigger the composition, but the contribution of the performer as a whole still remains an open field of exploration.

Far from asserting that all monodramas are the result of defined coauthoring processes, I feel that something between a post-modernist open attitude and the notion of the performer conventionally lived as a prolongation of the composer's voice has been lost somewhat. Furthermore, contemporary staging of monodramas drift away from their aesthetic premises to concede to the familiar territory of the "operatic." The absorption of these works to the "operatic" passes through the deployment of the "operatic voice" as performed voice ${ }^{55}$ :

Operatic voice does speak as well as sing, even though its effect may be to submerge what it is saying in its song. The point of contact is not locution but illocution. Operatic voice is above all performed voice. What it most immediately shares with language is the power of performative. ${ }^{56}$

The performative power of the operatic voice, especially in the realm of modernist music monologue, connects the ineffability of the stream of consciousness to its illocutionary quality, only to reinstate its bodily component. ${ }^{57}$

\footnotetext{
${ }^{54}$ Kaija Saariaho, Émilie (2008), program notes from the premiere, Orchestre de L'opéra de Lyon, soprano Karita Mattila, stage director Francois Girard, conductor Kazushi Ono (Lyon, France, 2008), http://www.musicsalesclassi cal.com/composer/work/1350/37049 (accessed May 4, 2017).

${ }^{55}$ Lawrence Kramer, "The Voice of/in Opera," in On Voice, edited by Walter Bernhart and Lawrence Kramer (Amsterdam, The Netherlands: Rodopi, 2014), 43-56.

${ }^{56}$ Kramer, "The Voice of/in Opera," 45.

${ }^{57}$ Kramer, "The Voice of/in Opera," 45.
} 
If monodrama still belongs to the realm of the operatic, I believe that this is indeed made possible by virtue of the illocutionary character of the performative voice and its embodied materiality.

In focusing on the one-act/one-singer genre, I have attempted here to confront its multiple instances with a body/voice theory and bring to light the singing body and its "present-ness" on stage as factors engendering current notions of twentieth-century monodrama. ${ }^{58}$ In what can now be deemed the historical monodramatic repertoire, the agency and primacy of the solo performer, both in the creative process and at a performative level, remains dangerously unsung. I believe instead that the notion itself of monodrama, as engendered through the performer's immersive embodiment, remains compelling in past and current practices and should be scrutinized as a dynamic layer of text.

Perhaps this is due to what Cavarero has deciphered as the misogynist perspective of the history of voice: "Song is more suited for the woman than for the man, above all because it is up to her to represent the sphere of the body as opposed to the more important realm of the spirit." ${ }^{59}$ Representation of female hysteria or more general madness in monodrama is therefore an emanation of "the symbolic patriarchal order that identifies the masculine with reason and the feminine with the body" in ways that marry or challenge the patriarchal attribution of the gendered roles. This would also be the key to understanding how and why the performer's body has disappeared from the hermeneutics of opera studies:

This voice becomes secondary, ephemeral, and inessential-reserved for women. Feminized from the start, the vocal aspect of speech and, furthermore, of song appear together as antagonistic elements in a rational, masculine sphere that centers itself, instead, on the semantic. To put it formulaically: woman sings, man thinks. ${ }^{60}$

On the compositional level, thanks to the numerous instances that have subverted this dualism, twenty-first-century musical monodrama has progressively infringed upon the unbalanced bond instituted between a male composer and the female voice as the carrier of a disruptive stream of consciousness. However, on the production level, the solo performer still seems to be denied the possibility to realize the sheer potential of her/his bodily agency. This is evident in the reification mechanisms operative during the casting of soloists who enjoy a clear marketable physiognomy, in the way their branded features are projected on stage, and in the necessity to fill the stage with a greater number of characters. All these exogenous solutions are perhaps a response to the fact that the multilayered yet solitary agency of the

\footnotetext{
${ }^{58}$ Jelena Novak, Postopera: Reinventing the Voice-Body (London: Ashgate, 2015), 152.

${ }^{59}$ Cavarero, "Introduction," For More than One Voice, 6.

${ }^{60}$ Caverero, "Introduction," 6.
} 
soloist incarnates at its best the "scandalous" epiphany of the singing body. Indeed, the current collaborative scenario has demonstrably changed the politics of solo performance in music theater; however, at the production level, is musical monodrama still an emanation of a patriarchal hierarchy? By empowering the performer at the production level, I aim to examine the performative legacies of these works and experiment with new means that emphasize the soloist's authorial drive in the extemporary performative act. Indeed, although questions remain unanswered at this stage, the processes engendered in turn provide cogent stimuli for further inquiry in both theoretical and practical fields.

\section{ORCID}

Francesca Placanica (i) http://orcid.org/0000-0003-0141-411X 